\title{
Effect of Leachate Recirculation on Biological Stability of Municipal Solid Waste Under Simi-Arid Conditions
}

\author{
Entessar Hussain $^{a, b}$ and Jathwa Al-Ameen ${ }^{b *}$ \\ ${ }^{a}$ Civil Engineering Department, University of Al-Qadisiyah, Iraq. \\ $b$ Environmental Engineering Department, University of Baghdad, Iraq.
}

\section{A R T I C LE INFO}

\section{Article history:}

Received 14 June 2019

Received in revised form 26 June 2019

Accepted 30 June 2019

\section{Keywords:}

Sanitary landfill

Bioreactor landfill

Leachate recirculation

\begin{abstract}
A B S T R A C T
The present study was conducted to monitor the quality of leachate generated from solid waste landfills operated under different mode over a period of 335 days using a bench scale lysimeters. Sixty six kg waste sample reflecting the typical municipal solid waste (MSW) streams generated in Al-Diwaniyah city open dump was used to fill both sanitary and bioreactor lysimeters to study the influence of leachate recirculation on quality of leachate in landfills located in semi-arid areas. Leachate quality is frequently monitored in terms of $\mathrm{pH}$, electrical conductivity (EC), chemical oxygen demand (COD), chloride, and total Kjeldahl nitrogen (TKN). The results show that $\mathrm{pH}$ and electrical conductivity values were clearly fluctuated in the rainy season, while in the dry season the values tend to decrease steadily with a close correlation between the chloride and electrical conductivity parameters. The study reveals that bioreactor landfill with leachate recirculation appears to be the most effective option in the removal of organic matter by $98 \%$ removal efficiency compared with 58\% removal efficiency in a sanitary landfill. The main difference between recirculation and non-recirculation options is determined through leachate quality.
\end{abstract}

(C) 2019 University of Al-Qadisiyah. All rights reserved.

\section{Introduction}

The landfill is one of the oldest and most economical means to dispose of municipal solid waste $\mathrm{MSW}_{\mathrm{s}}$. The area occupies ranges from several acres to hundreds[1]. As many management practices were implemented, recycling and reuse still lead to some waste that must be buried through landfill. However, despite the importance of landfill management, leachate disposal generated from landfills were unsatisfactory [2]. According to Nag et al. [3], leachate from landfills represents a potential threat to the ecosystem and surrounding population. The main objective of sanitary landfills is isolating the waste from the environment so that potential risks through a biological, chemical and physical transformation in $\mathrm{MSW}_{\mathrm{s}}$ could be eliminated. In general, the degree of isolation required in industrialized countries is more environmentally friendly than in developing countries [4]. The upgrading of existing landfill technologies from storage or containment a in sanitary landfills to a process-based approach is called the " bioreactor landfill " [5]. Due to the slow degradation of $\mathrm{MSW}_{\mathrm{s}}$ in sanitary landfills, bioreactors represent a new concept in solid waste management approach. Bioreactors are healthy landfills that promote the microbial degradation and clarify the use of microbial processes to transform and a stabilize the components of biodegradable organic waste in a short period of time by leachate recirculation into the waste body, contrary to sanitary landfill where the leachate drained out [6].

Unlike sanitary landfills, bioreactor landfills are designed to maximize water penetration. Bioreactor landfills accelerate biodegradation to stability by controlling the moisture content of the waste, recovering food and seed microorganisms through the leachate recirculation system [3]. The recovery of leachate through landfills helps to reduce the strength of organic matter, maintain the moisture content of landfills and reduce toxic substances[7], [8]. Infiltration of rainfall through the final cover is rare and short-lived in

* Corresponding author.

E-mail address: entesar_kareem@yahoo.com (Entesar Kareem) 
simi-arid region. In a semi-arid environment, $86 \%$ to $91 \%$ of the rainfall precipitate on landfill cover will be evaporated from these unvegetated landfill covers [9]. Thus, under semi-arid climatic conditions, the moisture content in landfills is limited, as a result, the degradation process is slow and limited. Leachate generation of landfills in the semi-arid region is influenced by a distinct dry season of up to 270 days a year, high temperatures, high solar radiation, and short period wet season with disappointing rainfall events within a few hours. The practice of recirculation leachate through landfill research was adopted to maintain the moisture content in a landfill, where moisture content is found to be a key factor in degradation process [7], [10] and [11]. Landfills in semi-arid climatic areas have not been well studied. The literature contains very limited information on the interaction between a dry climate and the quality of landfill leachate in different operation modes. In general, field investigations of landfills in semi-arid climates should be carried out to gather practical and reliable data, particularly leachate quality and degradation processes.

In this work, Bench scale lysimeters experiments were designed to obtain primary information about the major environmental concerns involved in $\mathrm{MSW}_{\mathrm{s}}$ landfill design for sustainable solid waste management in a semiarid climate, namely the quality of leachate and decomposition processes with a novel strategies in operation sanitary and bioreactor landfills by allowed to the leachate to percolate inside the waste body to amends the lack in moisture content during long dry seasons and assessment of recirculation of leachate in supported the metabolic processes, and enhancement degradation process in bioreactor landfill. In this study, the quality of leachate from sanitary and bioreactor landfill simulators are determined and compared. Leachate quality is investigated by measuring $\mathrm{pH}$, Electrical conductivity (EC), chemical oxygen demand (COD), chloride $\left(\mathrm{Cl}^{-}\right)$, and total Kjeldahl nitrogen (TKN). All analyses were passed through a $0.45 \mu \mathrm{m}$ membrane filter then tests according to the relevant methods described in the Standard Methods of APHA [12]. The quality parameters of leachate were monitored weekly for 335 days during rainy and dry seasons from December 2017 to October 2018.

\section{Material and Methodology.}

\subsection{Bench Scale Lysimeter Construction}

Two bench scales (BL) lysimeters were installed, the first lysimeter was operated as sanitary landfill (BLS), while the second operated as a bioreactor landfill with leachate recirculation (BLB).The bench lysimeters were made of high density polyethylene HDPE pipe with $40 \mathrm{~cm}$ in diameter and $70 \mathrm{~cm}$ in height, sealed from the top and bottom. The multipurpose vent was installed at the top cover in each lysimeter for gas escaping and for rainfall simulation addition or leachate recirculation.

The lysimeters were standing on a locally manufacturing a platform stand made of steel, elevated above the ground level about $40 \mathrm{~cm}$, to collect and direct generated leachate to a receiving tank of $(20 \mathrm{~L})$, located underneath the platform. A layer of compacted clay was provided at the bottom of each lysimeter to prevent downward movement of leachate followed by a geotextile layer to avoid clogging of drainage pipes holes. Gravel layer was applied for leachate filtration and drainage including perforated PVC draining pipe with a $25 \mathrm{~mm}$ valve equipped with faucet to drain leachate. A composite cover consisting of, sand and compacted clay respectively were placed over the fresh waste lysimeters to eliminate the emission of distasteful odor in the surrounding area. One layer approximately $50 \mathrm{~cm}$, equivalent to around $530 \mathrm{~kg} / \mathrm{m} 3$ compacted density in both lysimeters. Fig.1. provide a photo and schematic diagram of lysimeters.

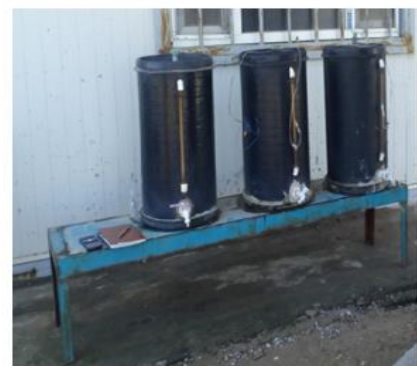

a

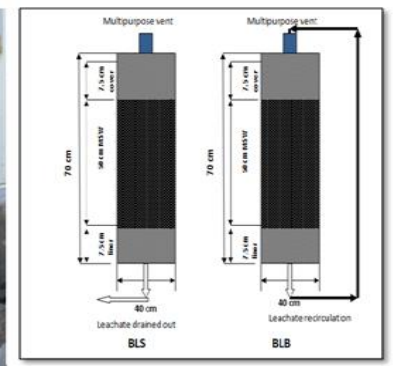

b
Figure 1: a) Photo of lysimeters; b) Schematic diagram of lysimeters

\subsection{Filling the Lysimeters}

A synthetic municipal solid waste identical to the composition of MSW in Al-Diwaniyah open dump was prepared to fill the bench scale lysimeter systems according to field survey adopted by [13]. The proposed component was manually shredded to a maximum size of $1 \mathrm{~cm}$ and buried in each lysimeter in one layer. The MSW deposited in lysimeters consists of $43 \%$ organic waste, $7.8 \%$ papre, $4.6 \%$ plastic, $4.8 \%$ metals, $5.6 \%$ glass, $5.2 \%$ textile, and $29 \%$ others wastes, followed by a thin cover layer of sand and clay.

\subsection{Ambient Boundaries and Operation}

Simi- arid climate in studying area (Al-Diwaniyah) city consists of the prolonged dry season of 7 months (May to September) and wet season with rare precipitation events within few hours as seen in Fig. 2. From the meteorological point of view, the climate of Al-Diwaniyah can be divided into two seasons as follows: Rainy season and dry seasons. The two benchscale landfills were constructed outdoor for allowed to a same actually environmental condition that landfills will expose, one of the bench landfill were operated as sanitary landfill BLS, while the other operated as bioreactor landfill with leachate recirculation BLB. The leachate recirculation was frequented once a week as the same as sampling frequency. The rain simulation was based on the average daily record; the addition of water was the same as the actual amount of precipitation that infiltrated into the landfill body in the case study. The added water was calculated as: (mean daily rainfall $*$ surface area of the reactor (i.e. 0.125 $\mathrm{m}^{2}$ ) as the surface area of the lysimeter was $0.125 \mathrm{~m}^{2}$ by assuming that all the amount of rainfall percolating through the landfill cover.

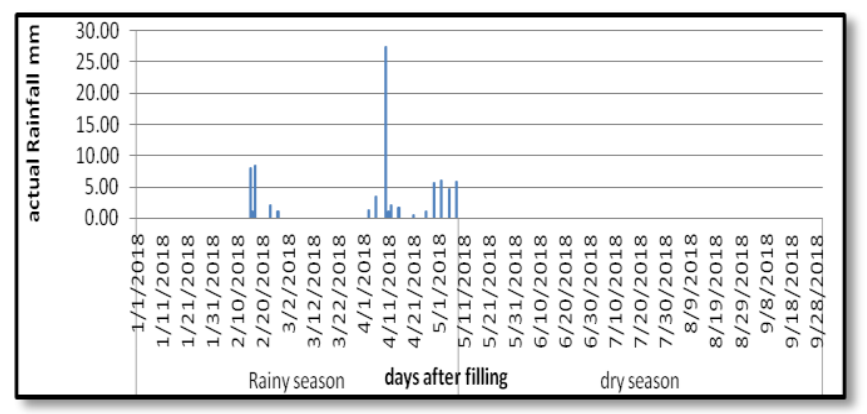

Figure 2: Rainfall Events During Period of the Study 


\section{Results and Discussion}

\section{1. $p H$}

The $\mathrm{pH}$ in leachate is considered to be the most significant parameter affecting leachate concentration in MSW landfills [14]. $\mathrm{pH}$ in the viewpoint of [15] was considered as an indicator of the aggressiveness of leachate, where metal dissolution is enhanced at low $\mathrm{pH}$ which is one of the characteristics of young landfill leachate [16]. Fig. 3. shows the variation of $\mathrm{pH}$ in relation to the increasing of the elapsed period in BLS and BLB landfills. The results show that the initial $\mathrm{pH}$ value of BLB samples was $7.11, \mathrm{pH}$ values decreased later to 6.33 due to acid accumulation because of organic matter hydrolysis producing organic acids as end products of acidogenesis bacteria metabolism besides the addition of leachate to the lysimeter causes a reduction in volatile fatty acid (VFA) concentration [14]. The lowest $\mathrm{pH}$ value in the BLB was 6.33 on day 49, $\mathrm{pH}$ values increased in BLB to 8.49 on day 229 of filling such increasing in $\mathrm{pH}$ values indicate the onset of methane production phase concurrent with hydrogen, carbon dioxide and VFA reduction [17].

In BLS the initial $\mathrm{pH}$ level was 7.26. $\mathrm{pH}$ values decreased later to 6.31, $\mathrm{pH}$ reduction can be attributed to the same reasons already mentioned above. The lowest $\mathrm{pH}$ value in BLS was 6.31 on day 65 of filling. $\mathrm{pH}$ values increased to 8.33 on day 271. According to [18] in an anaerobic systems $\mathrm{pH}$ will be less than 6 , with high organic content, long acidogenic phase, high VFA concentration, and insufficient alkalinity producing a potential inhibition to methanogenesis. On the contrary, high $\mathrm{pH}$ with low organic content, and sufficient alkalinity methanogenesis commenced.

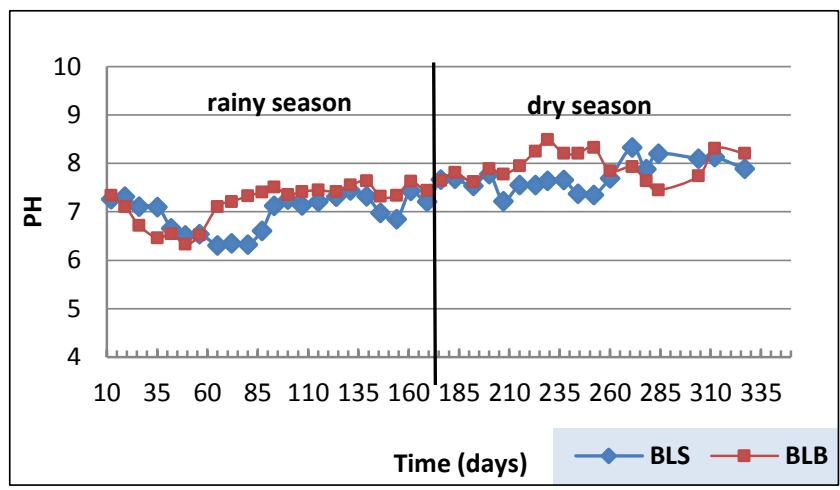

Figure 3: pH Variation in Leachate Samples for BLS and BLB Landfills

\subsection{Electrical Conductivity $(E C)$}

Electrical conductivity (EC) data were plotted versus days after filling to find out the ability of leachate to carry out electrical current based on the concentration of ions. Fig. 4. shows the variation of $\mathrm{EC}$ in relation to the increasing of elapsed period BLS and BLB landfills. In BLB, EC concentrations varied between 18 and $27 \mathrm{~ms} / \mathrm{cm}$ in the first 100 days period followed by a slight reduction in heavily raining days. Steadily values were detected in the dry season. In BLS the same trend was noticed with values ranging from $15 \mathrm{~ms} / \mathrm{cm}$ to $17 \mathrm{~ms} / \mathrm{cm}$ in the first 100 days. EC concentrations were higher in BLB lysimeter during an experimental trial due to leachate recirculation. EC values were clearly fluctuated in the rainy season, while in the dry season the values tend to decrease steadily except for later days and that may be due to high evaporation . Data were obtained coincide with the researchers [19] and [20].

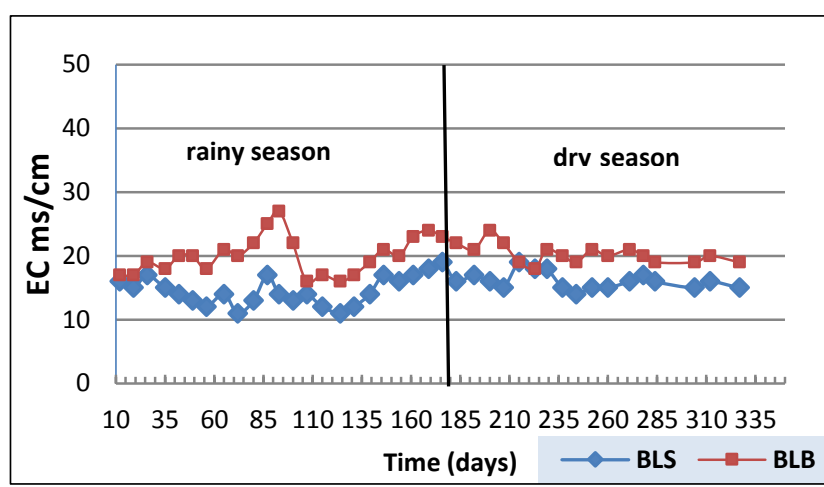

Figure 4: EC Variation in Leachate Samples for BLS and BLB

\section{Landfills}

\subsection{Chemical Oxygen Demand (COD)}

Organic matter released from the landfill lysimeters reflects landfill stabilization indirectly and evaluated by the COD concentration measured values [2]. As the overall strength of leachate measured by COD [21].

Fig. 5. shows the variation of COD in relation to the increasing of the elapsed period in (BLS and BLB)landfills . In BLB the results show that the highest $\mathrm{COD}$ concentration value was observed on day 65 of the filling, where it reached $47000 \mathrm{mg} / \mathrm{l}$. Values began to decrease later on gradually reaching a value of $550 \mathrm{mg} / \mathrm{l}$ on day 327 of the experiment. COD results in BLS differ from its counterpart in the BLB, where results showed that rainfall had effected. COD value increased gradually in the rainy season to reach its maximum value on day 100 reaching a value of $41200 \mathrm{mg} / \mathrm{l}$. Values dropped later till the end of the rainy season to reach to the value of $23100 \mathrm{mg} / \mathrm{l}$ on day 146 , while in the dry season the COD values increased to reach $35000 \mathrm{mg} / \mathrm{l}$ on day 192 then decreased gradually until the end of the experiment to reach $18000 \mathrm{mg} / \mathrm{l}$ on day 327 .

Reduction in COD values in both BLS and BLB is similar but the duration of the drop occurred was much shorter in bioreactor than in sanitary landfill, this finding coincides with [22]. Maximum reduction value in COD after 335 days of landfilling was accounted for BLB(98\%) while the lowest removal was accounted for BLS (58\%). The enhancement reduction value indicates the efficiency of the recirculation technique for providing in-situ leachate treatment as well as enhancement of degradation of organic matter.

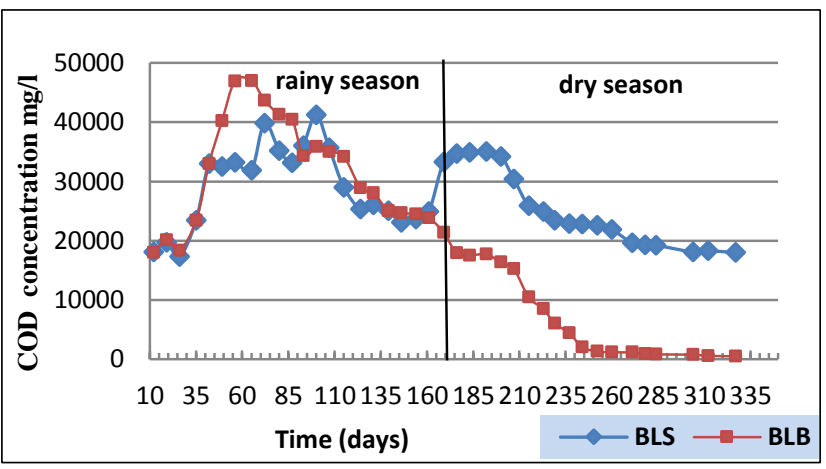

Figure 5 : COD Variation in Leachate Samples for BLS and BLB Landfills 


\subsection{Chloride}

Chloride in leachate is considered to be a very conservative anion that is only attenuated during dilution [14]. Fig. 6. shows the variation of chloride concentration in relation to the increasing of the elapsed period in BLB and BLS landfills. At the beginning of the landfill operation, chloride concentrations were 540 and $560 \mathrm{mg} / \mathrm{L}$ for the BLS and BLB, respectively. There is no considerable change in chloride concentrations of leachate generated from BLS and BLB simulators in the first 75 days of operation. After that period when the rainy season was onset, the dilution effects were significantly appeared in chloride values in BLS landfill, with a little effect on BLB landfill. In BLB landfill no considerable change was noticed during the dry season and last measurements were $520 \mathrm{mg} / \mathrm{l}$ was detected, while the last measurement for chloride in BLS was $190 \mathrm{mg} / \mathrm{l}$. Compared with conductivity in Fig. 4. , there is a close correlation between the two parameters observed at both lysimeters.

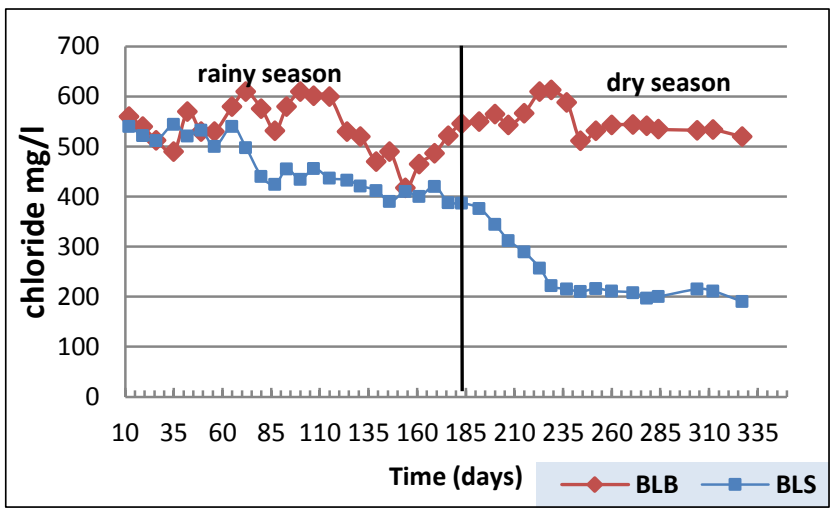

Figure 6 : Chloride Variation in Leachate Samples for BLS and BLB Landfills

\subsection{Total Kjeldahl Nitrogen (TKN)}

The TKN is the sum of organic nitrogen (Organic- $\mathrm{N})$ and $\mathrm{NH}_{4}-\mathrm{N}$ [12] Organic-Nrepresents come from an organic source like amino acids and urea, while the $\mathrm{NH}_{4}-\mathrm{N}$ is representative of inorganic matter. The variation in leachate nitrogenous compounds in terms of TKN of entire lysimeters operation are provided in Fig. 7.

The results reveal that TKN in leachate varied from 965 to 422 and from 820 to $398 \mathrm{mg} / \mathrm{L}$, for the leachate collection system BLS and BLB, respectively. Here, in general, the higher value of TKN was recorded for BLS against the other landfill type in the rainy season with fluctuation due to the dilution effect. In BLB the values of TKN reduce slowly with regular pattern through the rainy season. In dry season TKN was decreased and then remain almost constant throughout the experiment for both BLB and BLS. At the end of the experiment, TKN concentration is accumulated because of the absence of biological nitrification-denitrification process in anaerobic condition.

\section{Conclusion}

A comparison of the leachate quality from two bench-scale landfill lysimeters, operating under different conditions indicates the following results:
- Environmental conditions represented by rainfall had significant effects on the performance of the landfill and leachate quality.

- leachate quantity reflects the main difference between the recirculated and non-recirculated landfill operations.

- electrical conductivity and $\mathrm{pH}$ values were clearly fluctuated in rainy season due to dilution effects, while in the dry season the values tend to decrease steadily with a close correlation between the chloride and electrical conductivity parameters.

- Bioreactor landfill with leachate recirculation appears to be the most effective option in the removal of organic matter than sanitary landfill.

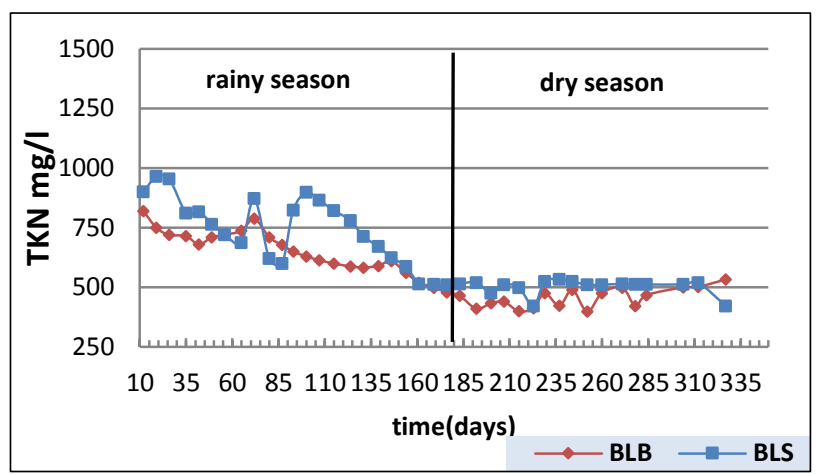

Figure 7: TKN Variation in Leachate Samples for BLS and BLB Landfills

\section{REFERENCES}

[1] Ling, H. I., Leshchinsky, D., Mohri, Y., and Kawabata, T. (1998). Estimation of municipal solid waste landfill settlement. Journal of geotechnical and geoenvironmental engineering, 124(1), pp. 21-28.

[2] He, R., Wei, X. M., Chen, M., Su, Y., and Tian, B. H. (2016). Effects of concentrated leachate injection modes on stabilization of landfilled waste. Environmental Science and Pollution Research, 23(4), pp. 3333-3341.

[3] Nag, M., Shimaoka, T., and Komiya, T. (2018). Influence of operations on leachate characteristics in the Aerobic-Anaerobic Landfill Method. Waste management, 78, 698-707.

[4] Abraham, M. (2000). Pollution Prevention: Fundamentals and Practice: Paul L. Bishop, Mc Graw-Hill Book Co.,(2000) ISBN: 0-07-366147-3, 716 pp.

[5] Chiemchaisri, C., Chiemchaisri, W., Nonthapund, U., and Sittichoktam, S. (2002, September). Acceleration of solid waste biodegradation in tropical landfill using bioreactor landfill concept. In 5th Asian symposium on academic activities for waste management (pp. 9 -12).

[6] Townsend, T., Kumar, D., and Ko, J. (2008). Bioreactor Landfill Operation. A Guide for Development, Implementation and Monitoring. Hinkley Center for Solid and Hazardous Waste Management, Gainesville,

[7] Huang, F. S., Hung, J. M., and Lu, C. J. (2012). Enhanced leachate recirculation and stabilization in a pilot landfill bioreactor in Taiwan. Waste Management and Research, 30(8), pp. 849-858.

[8] Slezak, R., Krzystek, L., and Ledakowicz, S. (2015). Degradation of municipal solid waste in simulated landfill bioreactors under aerobic conditions. Waste management, (43), pp. 293-299. 
[9] Shroff, V. S. (1999). An investigation of leachate production from MSW landfills in semi-arid climates [dissertation]. Alberta: University of Calgary

[10] Benson, C. H., Barlaz, M. A., Lane, D. T., and Rawe, J. M. (2007). Practice review of five bioreactor/recirculation landfills. Waste Management, 27(1), pp. 13-29.

[11] Bolyard, S. C., and Reinhart, D. R. (2016). Application of landfill treatment approaches for stabilization of municipal solid waste. Waste management, 55, pp.22-30.

[12] APHA. American Public Health Association, and American Water Works Association. (1998). Standard methods for the examination of water and wastewater. American public health association.

[13] Al-Ameen, Jathwa A., and Hussain Entessar K. (2018). "Impact Of SociEconomic Status On Biodegradable Content Of Residential Solid Waste At Point Of Generation." Journal Of Engineering And Sustainable Development 22(02 Part-4): 125.

[14] Bilgili, M. S., Demir, A., and Özkaya, B. (2007). Influence of leachate recirculation on aerobic and anaerobic decomposition of solid wastes. Journal of hazardous materials, 143(1-2), pp.177-183

[15] El-Fadel, M., Bou-Zeid, E., Chahine, W., and Alayli, B. (2002). Temporal variation of leachate quality from pre-sorted and baled municipal solid waste with high organic and moisture content. Waste management, 22(3), pp.269-282.
[16] Bozkurt, S., Moreno, L., and Neretnieks, I. (1999). Long-term fate of organics in waste deposits and its effect on metal release. Science of the Total Environment, 228(2-3), pp.135-152.

[17] Rout, C., and Sharma, A. (2010). Municipal solid waste stabilisation by leachate recirculation: A case study of Ambala City. International journal of environmental sciences, 1(4), pp. 645-655.

[18] Lavagnolo, M. C., Grossule, V., and Raga, R. (2018). Innovative dual-step management of semi-aerobic landfill in a tropical climate. Waste management, 74, pp. 302-311.

[19] Reinhart, D. R., and Basel Al-Yousfi, A. (1996). The impact of leachate recirculation on municipal solid waste landfill operating characteristics. Waste Management and Research, 14(4), pp. 337-346

[20] Warith, M. (2002). Bioreactor landfills: experimental and field results. Waste management, 22(1), pp.7-17.

[21] Knox, K., and Jones, P. H. (1979). Complexation characteristics of sanitary landfill leachates. Water Research, 13(9),pp. 839-846.

[22] Visvanathan, C., Tränkler, J., Kuruparan, P., and Xiaoning, Q. (2003, October). Effects of monsoon conditions on generation and composition of landfill leachate-lysimeter experiments with various input and design features. In Proceedings of the Sardinia, Ninth International Waste Management and Landfill Symposium. S. Margherita di Pula, Cagliari, Italy (pp. 6-10). 